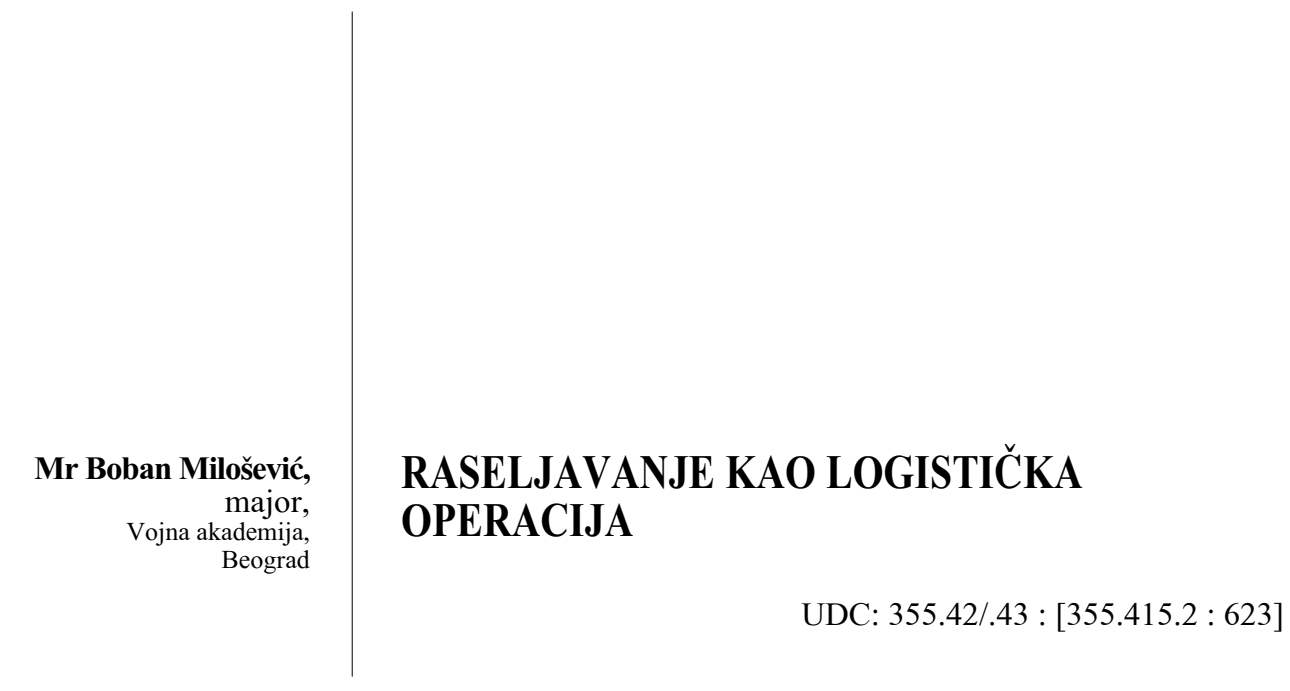

Rezime:

U ovom radu obraduje se problem raseljavanja materijalnih sredstava $i$ njihov razmeštaj na lokacijama, kao i mogućnost funkcionisanja elemenata sistema logističke podrške. U radu se određuje pojam raseljavanja. Opisan je način organizacije i tehnologije raseljavanja, gde se javlja potreba za optimizacijom različitih tereta i transportnih sredstava, kao $i$ planiranje raseljavanja. Za tehnološke zahteve, koji se javljaju pri raseljavanju, prikazan je način dimenzionisanja tehnoloških elemenata koji zadovoljavaju te zahteve.

Ključne reči: raseljavanje skladišta, tehnološki zahtevi, tehnološki elementi, organizacija, planiranje.

\title{
DISLOCATION AS LOGISTIC OPERATION
}

Summary:

Dislocation of material supplies (MS) has been discussed as well as the functioning of logistic support system elements at different locations. After the definition, organisation and technology of MS dislocation, the paper gives its planning and cases where optimisation of different loads and transportation means is required. The method of dimensioning technological elements meeting the technological requirements during dislocation has been presented as well.

Key words: dislocation, technological requirements, technological elements, organisation, planning.

\section{Uvod}

Skladišta (Sk) materijalnih rezervi su u toku rata veoma rentabilan cilj i često predstavljaju objekat napada. Zbog njihovog značaja za izvršavanje logističke podrške jedinica, a samim tim i izvođenje borbenih dejstava, neophodno je preduzimanje različitih mera i aktivnosti na njihovoj zaštiti. Nameće se pitanje na koji način obezbediti potrebne uslove, i kako organizovati raseljavanje skladišta materijalnih sredstava (MS) i tako ih zaštititi od uništenja i ostvariti optimalne uslove za snabdevanje jedinica. Raselja- vanje se realizuje sa jedinstvenim ciljem i po jedinstvenom planu. Upravljanje raseljavanjem načelno se vrši naređenjima i usmeravanjem, a svaka celina (skladište) ima relativno veliku autonomiju u samom planiranju i realizaciji raseljavanja. Upravo zbog toga može se steći pogrešan utisak da ne postoji jedinstven cilj $i$ jedinstven plan te aktivnosti. Da bi se izvršila zaštita MS neophodno je izvršiti raseljavanje stacionarnih skladišta u poljska skladišta, koja su razmeštena na pogodnim lokacijama. Razmeštajem se teži da se postigne njihovo usitnjavanje, sakrivanje i pogodniji raspored $\mathrm{u}$ prostoru 
u odnosu na krajnje korisnike, i na taj način spase od uništenja i omogući optimalna logistička podrška jedinica, što je i cilj raseljavanja.

\section{Planiranje raseljavanja}

Planiranje je stalni proces utvrđivanja ciljeva i zadataka, kao i pronalaženje optimalnih varijanti za njihovu realizaciju, pri čemu se odluke zasnivaju na stvarnim činjenicama i realnim procenama budućih događaja. To je proces kojim se definišu ciljevi koji se žele postići u narednom periodu, iznalaženja optimalnih resursa i načina za ostvarenje definisanih ciljeva i donošenja odluka o racionalnoj upotrebi resursa za ostvarenje definisanih ciljeva.

Polazne osnove za planiranje su:

- tehnologije (koja tehnologija utovara $\mathrm{i}$ istovara se primenjuje, odnosno koja može da se primeni);

- tehnološki elementi (u kom slučaju određeni tehnološki elementi mogu biti korišćeni, uzimajući u obzir one koji mogu biti primenjeni i koji stvarno stoje na raspolaganju);

- izbor lokacija (lokacije sa čvrstim objektima i lokacije u poljskim uslovima koje su na raspolaganju);

- organizacija (koja sredstva sa kojih lokacija i objekata moraju biti raseljena na druge lokacije, i kako to realizovati);

- dimenzionisanja tehnoloških elemenata;

- mogućnosti provere realnosti planova (simulacija, vežbovne aktivnosti).

Neophodan uslov za planiranje raseljavanja, kao i za realizaciju samih postupaka u okviru raseljavanja, jeste izbor i određivanje potrebnih resursa. Za prora- čun potrebnih resursa potrebno je odrediti osnovne elemente: količine MS koje treba raseliti, vreme određeno za raseljavanje, udaljenost lokacija i brzinu kretanja opterećenih ili praznih transportnih sredstava, broj utovarnih mesta u skladištu i broj istovarnih mesta na lokacijama, vreme trajanja raseljavanja $\mathrm{u}$ toku jednog dana, prosečne ili već utvrđene norme vremena pri realizovanju pojedinih radnji.

Tehnološki zahtevi su konkretizovani zadaci raseljavanja MS, raščlanjeni na veći broj parcijalnih zadataka: istovar $\mathrm{i}$ utovar, transport, manipulacija, skladištenje, rad u specifičnim uslovima.

Tehnološki elementi su neophodni za realizaciju tehnoloških zahteva: ljudi različitih kvalifikacija, motorna vozila, viljuškari, posebni tehnološki elementi, a mogu se pojaviti kontejneri, burad i kante, koji se javljaju i kao oblici tereta.

Proizvodnost ljudstva, kao jedan od najvažnijih elemenata pri utovaru ili istovaru MS, zavisi od: dužine nošenja, vrste i svojstava MS, vrste i razmeštaja vozila, umora i obučenosti ljudstva i raspoloživog vremena. Za uspešno izvršenje transporta moraju se maksimalno iskoristiti mogućnosti raspoloživih motornih vozila preduzimanjem sledećih mera:

- izbor najpovoljnijeg tipa i broja prevoznih sredstava na osnovu zadatka (komunikacija, dužina transporta, vrsta i količina MS i drugo);

- usklađivanje rada na utovarno-istovarnim mestima prema broju transportnih sredstava;

- određivanje sredstva za manipulaciju;

- određivanje optimalnog broja ljudi za rad na utovarno-istovarnim mestima. 
Rangiranje vozila vrši se na osnovu određenih kriterijuma, gde svaki kriterijum ima svoju relativnu važnost i potkriterijume koji ga bliže određuju.

Dimenzionisanjem tehnoloških elemenata optimizuje se transport MS. Primenom odgovarajućih modela, a u zavisnosti od tehnoloških zahteva, dimenzionisanje pojedinih tehnoloških elemenata može se izvršiti odgovarajućim analitičkim relacijama, za svaku odabranu tehnološku koncepciju, odnosno, tehnološko rešenje. Tipični primeri dimenzionisanja tehnoloških elemenata, $u$ zavisnosti od odabrane tehnološke koncepcije, jesu utovar i istovar vozila u jedinici Sk pri raseljavanju. Nakon izvršene kvantifikacije tehnoloških zahteva može se pristupiti dimenzionisanju tehnoloških elemenata, korišćenjem odgovarajućih postupaka koji u potpunosti uvažavaju sve karakteristike zbirnih tehnoloških zahteva za angažovanjem tehnoloških elemenata koji ih izvršavaju.

Pri izboru lokacije za razmeštaj elemenata sistema logističke podrške mora se voditi računa o karakteristikama koje te lokacije treba da zadovolje, kako bi se omogućio njihov smeštaj i rad. Izabrane lokacije treba da zadovoljavaju uslove $u$ pogledu veličine, pogodnosti za rad i smeštaj rezervi i zaliha, komunikativnosti i povezanosti, maskirnosti, mikroklimatskih uslova, pogodnosti za realizaciju procesa raseljavanja i slično. Uslovi za izbor lokacije su: dobri prilazni putevi - dobra komunikativnost, mogućnost rastresitog rasporeda objekata, maskirnost, mogućnost kružnog toka kretanja vozila, objekti na tvrdom i oceditom zemljištu i da je zaštićeno od bujica, da pruža dobro vodoobezbeđenje, povoljni uslovi za sprovođe- nje borbenog obezbeđenja, mogućnost korišćenja veštačkih ili prirodnih objekata $\mathrm{i}$ energetskih izvora. Kod hijerarhijskog struktuiranja kriterijuma izbora lokacije Sk, osnovni kriterijumi mogu da budu: taktičke karakteristike, karakteristike zemljišta, saobraćajne mogućnosti, organizaciono-tehnološki uslovi, klimatski, orografski i petrografski uslovi, položaj u odnosu na infrastrukturu na terenu i uslovi za život i rad ljudstva.

Raseljavanje je moguće planirati u više varijanti. Varijante planiranja zavise od konkretnog skladišta i konkretnih uslova, a mogu biti:

- prva varijanta (izrađuje se jedna varijanta plana raseljavanja kada izvršilac ima na raspolaganju samo ovaj plan i mora da postupi po njemu. Ova varijanta mogla bi se okarakterisati kao tvrda);

- druga varijanta (izrađuje se više varijanti plana raseljavanja, a zavisno od situacije određuje se koja će varijanta biti primenjena. U odnosu na prvu ovo je mekša varijanta);

- treća varijanta (izrađuje se planiranje resursa, mesta, lokacija i objekata za raseljavanje, a komanda skladišta, zavisno od situacije, realizuje raseljavanje fleksibilnije nego u slučaju prve dve varijante);

- četvrta varijanta (izrađuje se više varijanti plana raseljavanja, gde se plan radi po segmentima, vrši se segmentiranje varijanti - u skladu sa zahtevima vrši se po tehnološkim elementima, tehnologijama i lokacijama, gde su svi segmenti svake varijante autonomni, tako da pri realizaciji raseljavanja može da se vrši, zavisno od nastale situacije, kombinacija varijanti. Ovo je najfleksibilnija varijanta koja se može veoma lako prilagođavati 
novonastalim situacijama pri izvršavanju raseljavanja).

Realnost izrađenih varijanti planova moguće je proveriti simulacijom i vežbovnim aktivnostima.

\section{Organizacija i tehnologija raseljavanja}

Organizacija raseljavanja Sk planira se i obavlja u miru. Kao posledica ove aktivnosti nastaju planovi raseljavanja čiji je proces ažuriranja stalna aktivnost. Sa realizacijom raseljavanja otpočinje se po dobijanju naređenja, uz korekcije planova, zavisno od situacije u kojoj treba da se izvršava zadatak. U skladu sa izrađenim planom raseljavanja proces raseljavanja organizuje se kroz:

- organizaciju ručne manipulacije;

- organizaciju polumehanizovane manipulacije; pulacije;

- organizaciju mehanizovane mani-

- organizaciju transporta;

- usklađivanja propusne moći utovarno-istovarnih radnih mesta $i$ transportnih kapaciteta;

- informacionog sistema.

Za MS sa kojim nije izvršena paletizacija, ili u objektima u kojima nije moguća upotreba sredstava za manipulaciju, organizuje se ručna manipulacija. Pri određivanju broja ljudi za ručno manipulisanje mogu se primenjivati iskustvene norme do kojih se došlo pri izvođenju vežbi ili tokom obuke. Iskustvene norme kreću se od 0,4 (za ljudstvo slabije fizičke sposobnosti i uvežbanosti) do 1,2 tone tereta po čoveku u toku jednog časa, $\mathrm{s}$ tim što se posle četiri časa neprekidnog rada daje odmor ljudstvu.
Iskustveni podaci, iz pravila transporta i organizacije rada, mogu poslužiti pri određivanju približnog broja lica za izvršenje utovara i istovara (za ručnu manipulaciju), i prikazani su u tabeli 1 .

Tabela 1 Potreban broj lica za utovar i istovar vozila

\begin{tabular}{|c|c|c|c|c|}
\hline Naziv & $\begin{array}{c}\text { Broj } \\
\text { lica }\end{array}$ & $\begin{array}{c}\text { Režim } \\
\text { rada }\end{array}$ & $\begin{array}{c}\text { Ispred } \\
\text { vozila }\end{array}$ & $\begin{array}{c}\text { Na } \\
\text { vozilu }\end{array}$ \\
\hline $\begin{array}{c}\mathrm{m} / \mathrm{v} \text { ili prikolica } \\
\text { do 7 t }\end{array}$ & 4 & normalan & 2 & 2 \\
\hline $\begin{array}{c}\mathrm{m} / \mathrm{v} \text { i prikolica } \\
\text { do 7 t }\end{array}$ & 8 & normalan & $2+2$ & $2+2$ \\
\hline $\begin{array}{c}\mathrm{m} / \mathrm{v} \text { ili prikolica } \\
\text { preko 7 t }\end{array}$ & $6-8$ & ubrzan & $3-4$ & $3-4$ \\
\hline $\begin{array}{c}\mathrm{m} / \mathrm{v} \text { i prikolica } \\
\text { preko 7 t }\end{array}$ & $12-16$ & ubrzan & $\begin{array}{c}3+3 \\
\text { ili } 4+4\end{array}$ & $\begin{array}{c}3+3 \\
\text { ili } 4+4\end{array}$ \\
\hline
\end{tabular}

Potrebno vreme za utovar ili istovar vozila određene nosivosti prikazano je u tabeli 2. U norme utovara $\mathrm{i}$ istovara uračunato je i vreme potrebno za pripremu vozila i dokumenata pre i posle obavljanja navedenih radnji.

Tabela 2

Vreme utovara ili istovara vozila

\begin{tabular}{|c|c|c|}
\hline Vozilo nosivosti & \multicolumn{2}{|c|}{ Norme (minuta) } \\
\cline { 2 - 3 } u tonama & utovar & istovar \\
\hline do 1,5 & 19 & 19 \\
\hline $1,5-2,5$ & 20 & 20 \\
\hline $2,5-4$ & 24 & 24 \\
\hline $4-7$ & 29 & 29 \\
\hline $7-12$ & 37 & 37 \\
\hline $12-15$ & 45 & 45 \\
\hline
\end{tabular}

Opšte vremenske norme, u zavisnosti od nosivosti vozila, navedene u tabeli 2 , jesu privredne norme, a u VSCG ove norme, shodno stepenu obučenosti lica za utovar i istovar kao i uslovima obavljanja navedenih radnji, treba povećati za 10 do $20 \%$.

Polumehanizovana manipulacija vrši se tako što se deo radova obavlja ručno, a deo upotrebom sredstava za mehanizovanu manipulaciju. 
Mehanizovana manipulacija obavlja se tamo gde je izvršena paletizacija MS. $\mathrm{Za}$ manipulaciju u terenskim uslovima mogu se koristiti traktori sa uređajima za podizanje tereta, dizalice na motornim vozilima sa specijalnim dodacima za manipulaciju sa paletizovanim MS i specijalni terenski viljuškari.

Transport MS može se realizovati: formiranjem i slanjem kolone motornih vozila, slanjem manjih grupa motornih vozila i slanjem pojedinačnih vozila neposredno posle izvršenog utovara. Realizacija transporta zavisiće od konkretne situacije u okviru koje se obavlja prevoženje - stanja puteva, mogućnosti saobraćajnog i borbenog obezbeđenja i drugih uslova.

Natovarena vozila moraju se što manje zadržavati u rejonu stacionarnog skladišta, što ukazuje da je najcelishodnija organizacija transporta slanje vozila u poljsko skladište neposredno nakon utovara.

Pri utovaru ili istovaru MS, a radi smanjenja vremena zadržavanja vozila, $u$ skladištu se određuje potreban broj radnih mesta koji zavisi od količine MS, broja vozila, broja sredstava za manipulaciju i broja radne snage.

Propusna moć, pri utovaru ili istovaru u skladištu, zavisi od broja radnih mesta i njihove propusne moći, i iznosi:

- na osnovu poznate količine MS $Q_{c}=N \cdot Q_{c m}$,

- za poznati broj vozila

$\begin{aligned} N v c= & N \cdot A_{c m} . \\ & \text { Efikasnost i racionalnost organizova- }\end{aligned}$ nja raseljavanja postiže se ako se uskladi ritam rada na utovaru $\mathrm{u}$ stacionarnom skladištu i ritam rada na istovaru u poljskom skladištu. Ritam rada predstavlja vreme između otpravljanja utovarnih ili istovarnih vozila iz skladišta [2]:

$R=t_{u(i)}=Q_{v} \cdot t_{1}$

- za jedno radno mesto, ritam rada će biti jednak vremenu koje je potrebno za utovar ili istovar jednog vozila;

- za više radnih mesta, smanjuje se vreme između spremnosti vozila za pokret srazmerno broju mesta:

$R=\frac{Q_{v} \cdot t_{1}}{N}$

Interval vožnje predstavlja vreme između dva uzastopna dolaska vozila na utovarno ili istovarno mesto, $i$ on je jednak obrtu vozila ako se za transport koristi jedno vozilo:

$I_{v}=\mathrm{t}_{0}$

a ako ima više vozila $\left(N v_{1}\right)$ onda će se interval pristizanja smanjiti:

$I_{v}=\frac{t_{0}}{N v_{1}}(h)$

Ukoliko su ritam rada i interval pristizanja vozila izjednačeni $(R=I v)$, onda je postignuta racionalna organizacija raseljavanja.

Iz ovog uslova moguće je odrediti broj vozila, broj radnih mesta i uticati na vreme utovara-istovara [2]:

- broj radnih mesta $N=\frac{N v_{1} \cdot t_{u(i)}}{t_{0}}$

- broj vozila $N v_{1}=\frac{N \cdot t_{0}}{t_{u(i)}}$

Ukoliko je broj vozila $N v_{1}<N v$, onda broj radnih mesta predstavlja ograničenje. To znači da se mora povećati broj 
radnih mesta ili smanjiti vreme utovaraistovara (produžiti vreme izvršenja zadatka ako vreme raseljavanja nije ograničeno), s obzirom na to da je naređenjem i vreme raseljavanja ograničeno. Onda je broj radnih mesta:

$$
N=\frac{N v \cdot t_{u(i)}}{t_{0}}
$$

Odnos toka informacija i toka materijala između upravnih i izvršnih organa pri raseljavanju ima veliki značaj radi praćenja kretanja MS u toku preseljavanja skladišta.

\section{Raseljavanje materijalnih sredstava}

Raseljavanje MS je proces premeštanja iz stacionarnih skladišta, vantrupnog ešelona, po unapred utvrđenom planu na unapred određene i pripremljene rejone za raseljavanje. Realizuje se radi zaštite od mogućeg dejstva neprijatelja i uništenja, i obezbeđenja mogućnosti za snabdevanje jedinica MS. Odluku o izradi planova raseljavanja po varijantama donosi komanda strategijske grupacije.

Raseljavanje skladišta jedna je od najsloženijih radnji. Uslovi raseljavanja su različiti i imaju različit uticaj na tok izvršenja zavisno od:

- vremena otpočinjanja agresije;

- izvršene mobilizacije;

- obima raseljavanja;

- meteoroloških i klimatskih uslova;

- stanja resursa;

- neposredne stalne ugroženosti skladišta od dejstava iz vazdušnog prostora, itd.

Pored opštih uslova, raseljavanje se dodatno znatno usložava: uporednim izvr- šavanjem funkcionalnih zadataka skladišta, mobilizacije skladišta, jedinica čija su sredstva uskladištena u skladištu; jedinica koju realizuju neka skladišta i uslova izvršenja koja se menjaju u vremenu.

Raseljavanje po obimu može biti delimično ili potpuno. Do delimičnog raseljavanja MS može doći u situaciji kada nije sigurno da će doći do agresije, pa se raseljavaju samo prioritetni MS. U pitanju je ekonomski faktor, a ako dalji razvoj situacije ukaže na neminovnost agresije izvršava se potpuno raseljavanje. Proces raseljavanja može se izvoditi danju, noću ili i danju i noću u svim vremenskim uslovima, koji mogu biti i ograničavajući faktor.

\section{Dekompozicija stacionarnog skladišta}

Stacionarna skladišta izgrađuju se u miru i namenski, a objekti se grade od čvrstog materijala, tako da zadovoljavaju odgovarajuće uslove za čuvanje MS u skladu sa njihovim specifičnostima. Formiraju se na trupnom nivou za čuvanje ratnih rezervi do mobilizacije, a na vantrupnom nivou za neprekidan rad. Dekompozicija stacionarnog skladišta vrši se:

- po prostoru (skladište na više mesta - svako mesto ima jednu ili više lokacija - svaka lokacija ima jedan ili više objekata);

- po dugovanju (jedan rukovalac jedan objekat - jedna lokacija - jedno mesto i jedan rukovalac - više mesta više lokacija - više objekata).

\section{Dekompozicija poljskog skladišta}

Pri raseljavanju stacionarnog skladišta formira se poljsko skladište, prema već sačinjenom planu, na određenom 
mestu, lokacijama i objektima u kojima će se skladištiti MS. Dekompozicija poljskog skladišta obavlja se:

- po prostoru (stacionarno skladište - jedno ili više poljskih skladišta - jedno ili više mesta - jedna ili više lokacija jedan ili više objekata);

- po dugovanju, jedan rukovalac jedan objekat - jedna lokacija - jedno mesto i jedan rukovalac - više mesta više lokacija - više objekata).

Pri dekompoziciji skladišta, osnova dekompozicije je po objektima tako da svaki objekat kao podsistem skladišta predstavlja zasebnu celinu.

\section{Opšta slika raseljavanja}

Pri izvršenju raseljavanja rukovaoci, prema planu raseljavanja, počinju da prazne objekte u kojima su bila smeštena MS, organizuju utovar na vozila, izrađuju propratnu dokumentaciju i šalju vozila na odredišta u poljska skladišta gde će MS da prime rukovaoci i da izvrše skladištenje primljenih MS (opšta slika raseljavanja prikazana je na slici 1).
U toku izvršenja pa do njegovog završetka, MS koja se raseljavaju nalaziće se u stacionarnom skladištu, na utovaru u vozilima, na vozilima u pokretu, na istovaru u objektima poljskih skladišta i u objektima poljskih skladišta. To znači da rukovaoci stacionarnog skladišta moraju ažurno izrađivati propratnu dokumentaciju, za MS koja se šalju, i da pomoću nje kontrolišu kretanje transportovanih MS.

\section{Poljska skladišta}

Poljska skladišta formiraju se neposredno pred rat i u toku rata, radi raseljavanja stacionarnih skladišta, distribucije po teritoriji ili radi približavanja borbenom poretku zbog skraćivanja puteva dotura $\mathrm{i}$ evakuacije, $\mathrm{i}$ ona su privremenog karaktera.

Skladištenje, čuvanje, manipulacija i distribucija MS, a posebno održavanje uskladištenih MS i očuvanje njihovih kvalitativnih i kvantitativnih svojstava, kao i funkcionalnosti upotrebe u svim vremenskim i drugim uslovima koji se

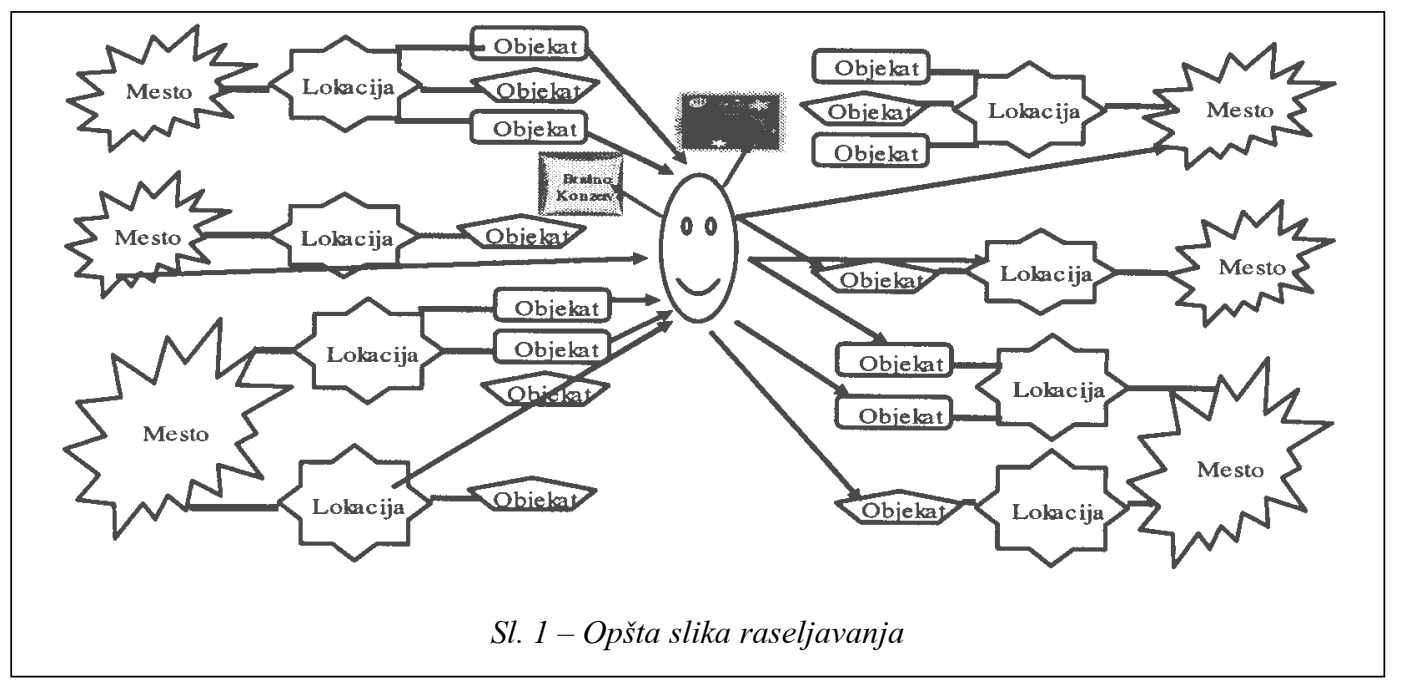




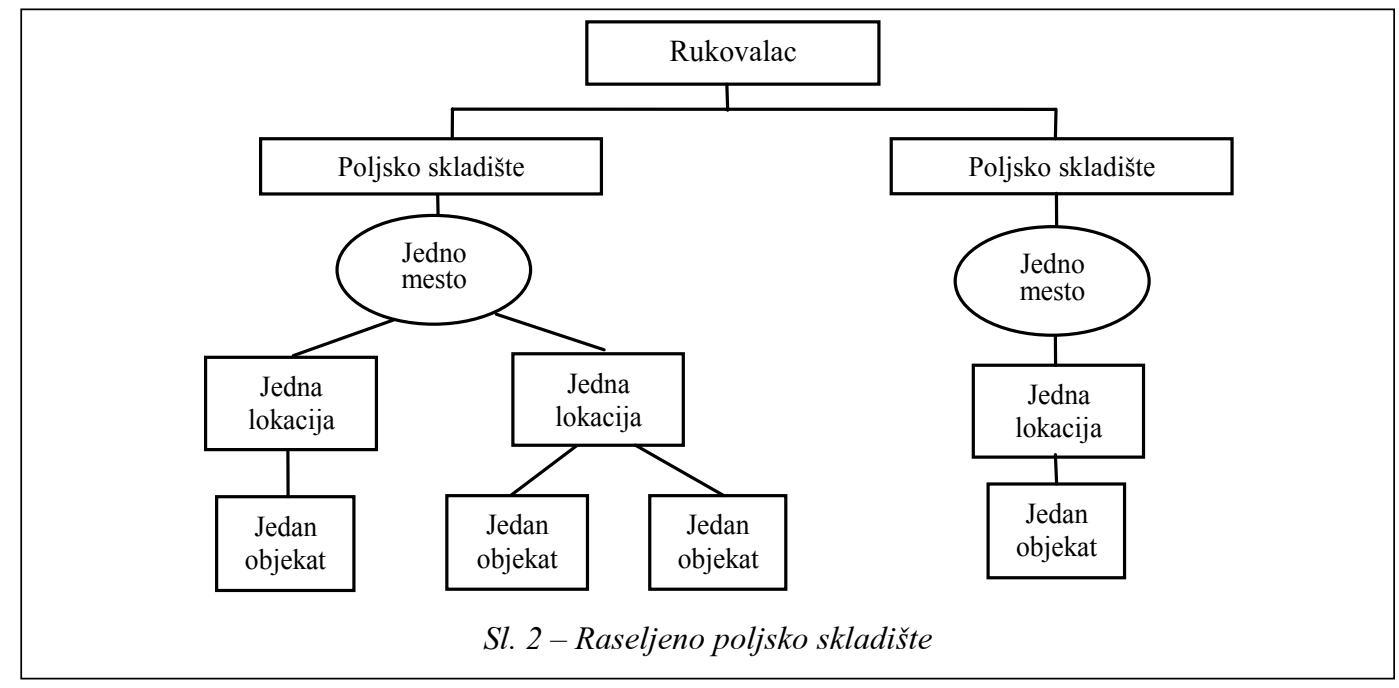

kao značajan i nezaobilazan faktor odražavaju na održavanje MS, predstavljaju bitan faktor u održavanju visokog nivoa borbene gotovosti jedinice.

Skladištenje MS u kvalitetnim objektima poljskog skladišta, i njihovo održavanje u uslovima u kojima su uskladišteni, kao jedna od funkcija snabdevanja, u sistemu logističke podrške jedinica ima veliki značaj. To je osnovni polazišni reper koji se mora zadovoljiti pri određivanju skladišnog prostora za MS.

\section{Pojavni oblici tereta}

Materijalna sredstva se sagledavaju kao pojavni oblici tereta, odnosno kao objekat raseljavanja po svojim fizičko-hemijskim osobinama, obliku i dimenzijama, kompatibilnosti u odnosu na transport i skladištenje, iz čega proizilaze zahtevi za tehnologiju i organizaciju manipulacije i transporta MS. Pojavni oblici tereta su: sanduci, palete, bačve, kante, kutije, komadni teret nepravilnog oblika, teret $u$ rasutom stanju, teret u tečnom stanju, palete, kontejneri, osnovna sredstva, itd.

\section{Kriterijumi za ocenu uspešnosti raseljavanja}

Osnovni kriterijumi za ocenu uspešnosti raseljavanja su:

- vreme raseljavanja koje treba da bude proizvod proračuna vremena raseljavanja, a ne zadata veličina;

- funkcionalnost skladišta, koja se ogleda u toku raseljavanja i nakon završenog raseljavanja.

Vreme raseljavanja treba da bude rezultat proračuna resursa na osnovu tehnologije i usklađivanja rada utovarno-istovarnih stanica $\mathrm{i}$ transportnih kapaciteta i dinamike raseljavanja koja je prikazana na slici 3.

\section{Informaciona podrška}

Materijalni tokovi predstavljaju puteve kojima se MS prilikom raseljavanja kreću iz stacionarnih skladišta u poljska i obratno (slika 4). Materijalne tokove treba organizovati putem linije izvršnih organa-rukovaoca. Materijalna sredstva kreću se od stacionarnog skladišta ka 

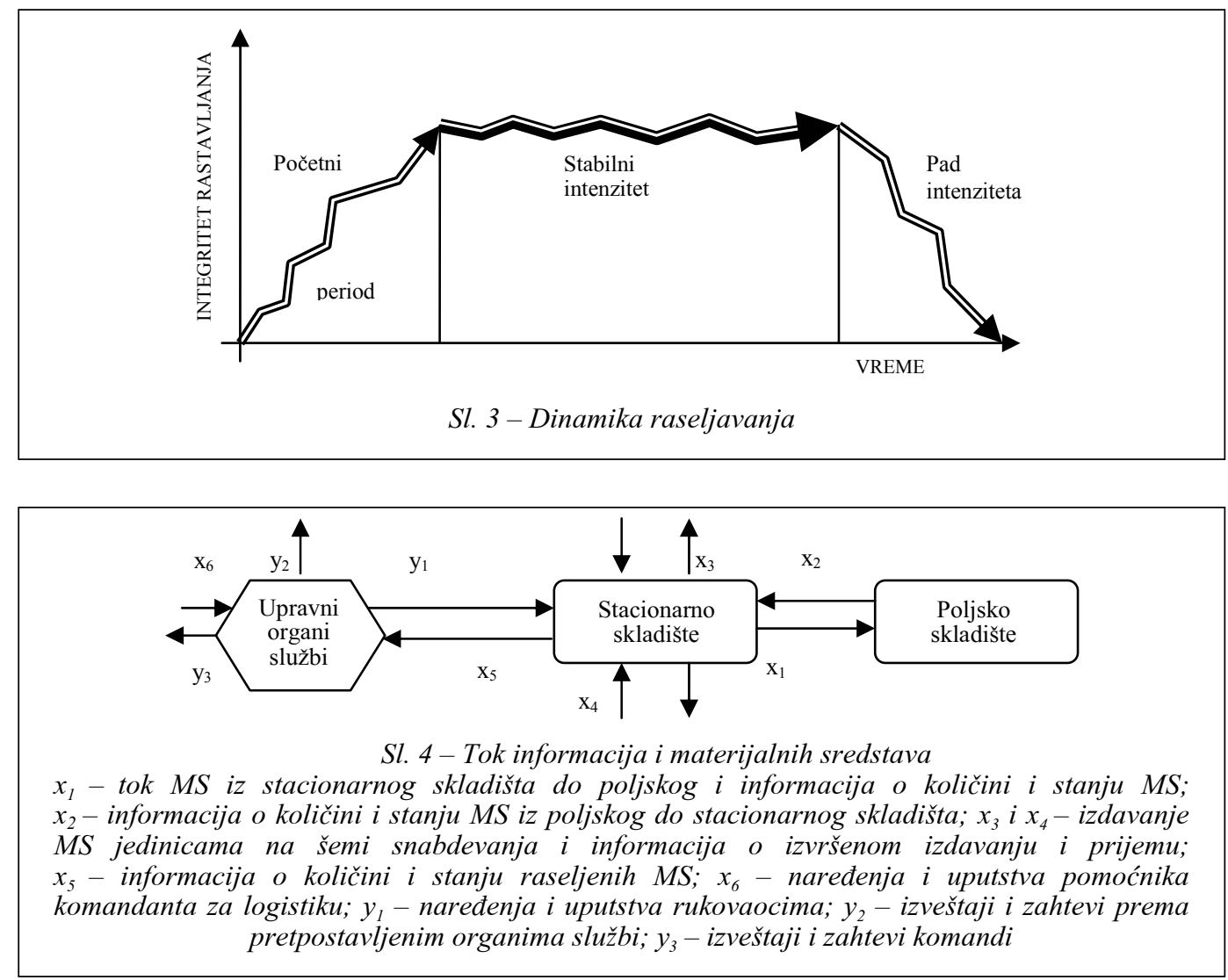

poljskom i obratno, s tim što putevi treba da budu isti. Tokom raseljavanja neophodno je pratiti stanje gde je šta raseljeno da se ne bi izgubila evidencija gde se šta od MS nalazi i tako naruši prava informacija o količini sredstava kojima se raspolaže, što bi narušilo normalno funkcionisanje skladišta. Da bi se to efikasno sprovelo potrebna su dva dokumenta dokument o izlazu MS iz skladišta i dokument o ulazu MS u skladište. Nakon završenog zadatka rukovaoci izveštavaju upravni organ linijom informisanja.

Informatička podrška je jedan od značajnih elemenata kao realni oslonac $u$ komandovanju i funkcionisanju skladišta. Pomoću informacionog sistema tre- balo bi obezbediti automatizaciju celokupnog rada skladišta preko sledećih funkcija:

- praćenja i izveštavanja o kvantitativnom stanju MS;

- praćenja i izveštavanja o rokovima upotrebe MS;

- vođenja materijalnog knjigovodstva;

- informatičke podrške procesima rada skladišta.

Puni efekti primene računarskih sistema u logističkoj podršci, ostvariće se ne samo primenom savremenih sredstava automatizacije, već i standardizacijom logističkog informacionog sistema u hardveru i softveru. Standardizacijom će se obezbediti kompaktibilnost, jednostav- 
nija obuka, smanjenje troškova i optimalna logistička podrška.

\section{Zaključak}

Savremeni način vođenja rata nameće zahtev za efikasnom logističkom podrškom. Svi ratovi vođeni posle Drugog svetskog rata ukazuju na prvorazrednu ulogu i značaj teritorijalnih skladišta, što je ujedno i glavna karakteristika u posleratnom periodu u odnosu na mesto i ulogu skladišta. Samo raseljavanje predstavlja složenu aktivnost $u$ okviru koje treba obezbediti najviše moguće mere zaštite MS od uništenja i oštećenja, kao i maksimalnu zaštitu ljudstva koje vrši manipulaciju MS.

Raseljavanje ima strategijski značaj, pošto se njegovom uspešnom realizacijom čuvaju MS od uništenja, čime se obezbeđuje i borbena gotovost jedinica i njihova sposobnost za uspešno vođenje oružane borbe. $\mathrm{O}$ raseljavanju postoje is- kustva iz ranijeg perioda koja su se dopunjavala i menjala u toku agresije NATO-a na našu zemlju. Koriste se i saznanja iz mirnodopskih vežbovnih uslova raseljavanja, skladištenja, čuvanja i manipulisanja MS, kao i teorijska saznanja o ostvarivanju optimalnih uslova snabdevanja jedinica MS u ratu. Tako prikupljena saznanja treba oblikovati, formalizovati i modelovati, kako bi bila lako i brzo usvojena i primenljiva.

\section{Literatura:}

[1] Maksić, R.: Osnovno snabdevanje municijom, VTA KoV JNA, Zagreb, 1986

[2] Pantelić, V.: Snabdevanje tehničkim materijalnim sredstvima, CVŠ KOV JNA, Zagreb, 1986.

[3] Pravilo pozadinsko obezbeđenje oružanih snaga SFRJ u ratu, SSNO, 1989.

[4] Mladenović, V.: Savremena metoda skladištenja, manipulisanja i transporta, CVTŠ KoV JNA, Zagreb, 1980.

[5] Mišković, V.; Milićević, M.; Stanojević, P.: Modeli ocenjivanja i rangiranja varijantnih rešenja organizaciono-tehnoloških sistema, Vojnotehnički glasnik, 2/2001.

[6] Milošević, B.: Raseljavanje, disperzija materijalnih sredstava i izmeštanje kapaciteta intendantske službe u mobilizaciji i ratu, magistarski rad, VA VJ, Beograd, 2002. 